\title{
ansa-VANADOCENE COMPLEXES - SYNTHESES, STRUCTURES AND LIGAND EXCHANGE REACTIONS*
}

\author{
Birgit DoreR', Marc-Heinrich Prosenc, Ursula RIEF and Hans-Herbert BrINTZINGER ${ }^{2}$ \\ Fakultät für Chemie, Universität Konstanz, 78434 Konstanz, Germany; \\ e-mail: ${ }^{1}$ dorerb@otecsun 1.hou.xvh.bp.com, ${ }^{2}$ hans.brintzinger@uni-konstanz.de
}

Dedicated to Dr Karel Mach on the occasion of his 60th birthday.

\begin{abstract}
Tetramethylethano-bridged vanadocene dichlorides $\left(\mathrm{CH}_{3}\right)_{4} \mathrm{C}_{2}\left(3-\mathrm{R}_{-} \mathrm{C}_{5} \mathrm{H}_{3}\right)_{2} \mathrm{VCl}_{2}$ with $\mathrm{R}=\mathrm{H}$, Me, $t$ - $\mathrm{Bu}$ are obtained by reacting the corresponding ligand $\mathrm{MgCl}$ salts with vanadium(III) acetylacetonato compounds, followed by oxidation with $\mathrm{PCl}_{3}$ or $\mathrm{AgCl}$. Smooth ligand exchange reactions of these ansa-vanadocene dichlorides afford acetylacetonato cations and binaphtholate complexes; from these, the dichlorides are regenerated by exposure to $\mathrm{MgCl}_{2}$ in THF solution. Separation of meso and rac isomers (as well as enantiomer separation) is achieved via corresponding binaphtholate complexes; conversion to the vanadium(III) diisonitrile cations $\left(\mathrm{CH}_{3}\right)_{4} \mathrm{C}_{2}\left(3-\mathrm{R}-\mathrm{C}_{5} \mathrm{H}_{3}\right)_{2} \mathrm{~V}(\mathrm{CNt} \text { - } \mathrm{Bu})_{2}^{+}$allows an assessment of diastereoisomer ratios by ${ }^{1} \mathrm{H}$ NMR. Lewis-acidic bistriflate derivatives of these ansa-vanadocene complexes are obtained from the dichlorides by reaction with silver triflate.

Key words: ansa-Metallocenes; Vanadium; Acetylacetonato complex; Chiral; Enantioseparation.
\end{abstract}

Structures, electronic properties and reactivities of a great diversity of titanocene complexes have been admirably elucidated over the last three decades in more than eighty publications by Karel Mach and his coworkers ${ }^{2}$. That comparable insights are largely lacking in regard to related vanadocene and chromocene complexes is undoubtedly connected with the generally more difficult access to this class of metallocenes, especially to their ring-bridged representatives ${ }^{1,3}$. In order to open up this field to more incisive investigations, also with regard to possible application to asymmetric catalysis, we have tried to develop improved methods for the synthesis of ansa-vanadocene compounds. In an earlier publication, we have reported ${ }^{3}$ that the synthesis of ethano-bridged vanadocene chlorides suffers from the reduction of $\mathrm{VCl}_{4}$ by the dianionic ligand compound $\left(\mathrm{CH}_{3}\right)_{4} \mathrm{C}_{2}\left(\mathrm{C}_{5} \mathrm{H}_{4} \mathrm{Li}\right)_{2}$, and that improved yields are obtained by reaction of $\mathrm{VCl}_{4}$ or - prefereably - of $\mathrm{VCl}_{3}$ with the dimagnesium salt $\left(\mathrm{CH}_{3}\right)_{4} \mathrm{C}_{2}\left(\mathrm{C}_{5} \mathrm{H}_{4} \mathrm{MgCl}\right)_{2}(1 \mathrm{a})$.

* Part XXXVII in the series on ansal-Metallocene Derivatives; Part XXXVI: see ref. ${ }^{1}$. 
Further studies with bis(acetylacetonato)vanadium dichloride ${ }^{4}$, (acac) ${ }_{2} \mathrm{VCl}_{2}$, showed that this compound is less easily reduced than $\mathrm{VCl}_{4}\left(E_{\mathrm{p}}\left((\mathrm{acac})_{2} \mathrm{VCl}_{2}\right)=-0.18 \mathrm{~V}\right.$, $E_{\mathrm{p}}\left(\mathrm{VCl}_{4}(\mathrm{THF})_{2}\right)=-0.06 \mathrm{~V}$ in THF solution), but that even this starting material produces only the vanadium(III) monochloride complex $\left(\mathrm{CH}_{3}\right)_{4} \mathrm{C}_{2}\left(\mathrm{C}_{5} \mathrm{H}_{4}\right)_{2} \mathrm{VCl}$ (2a). Control experiments showed that (acac) ${ }_{2} \mathrm{VCl}_{2}$ is reduced to (acac) ${ }_{2} \mathrm{VCl}$ when reacted with half an equivalent of the cyclopentadienyl magnesium compound $\mathbf{1 a}$. The reduced acetylacetonato compound, (acac) ${ }_{2} \mathrm{VCl}$, thus appeared to be an even more suitable starting material for ansa-vanadocene syntheses; in the following we report applications of this concept to syntheses of unsubstituted and ring-substituted, tetramethylethanobridged vanadocene complexes $\left(\mathrm{CH}_{3}\right)_{4} \mathrm{C}_{2}\left(3-\mathrm{R}-\mathrm{C}_{5} \mathrm{H}_{3}\right)_{2} \mathrm{VCl}_{2}$ (3) with $\mathrm{R}=\mathrm{H}(3 \mathrm{a}), \mathrm{Me}$ (3b) or $t$ - Bu (3c).

\section{RESULTS AND DISCUSSION}

ansa-Vanadocene Syntheses

Reaction of the vanadium(III) compound (acac) $2 \mathrm{VCl}$ with one equivalent of cyclopentadienyl potassium leads to substitution of the chloride ligand under formation of $\mathrm{KCl}$ and $\mathrm{C}_{5} \mathrm{H}_{5} \mathrm{~V}$ (acac) $)_{2}$ (previously prepared by reaction of $\mathrm{CpVCl}_{2}\left(\mathrm{PMe}_{3}\right)_{2}$ with acetylacetone ${ }^{5}$ ). Additional amounts of $\mathrm{C}_{5} \mathrm{H}_{5} \mathrm{~K}$ give only unidentified reduction products; no dicyclopentadienyl vanadium species are observed in this reaction system. With $\mathrm{C}_{5} \mathrm{H}_{5} \mathrm{MgCl}$, however, either (acac) $)_{2} \mathrm{VCl}$ or $\left(\mathrm{C}_{5} \mathrm{H}_{5}\right) \mathrm{V}(\mathrm{acac})_{2}$ react to give vanadocene monochloride, $\left(\mathrm{C}_{5} \mathrm{H}_{5}\right)_{2} \mathrm{VCl}$, from which $\left(\mathrm{C}_{5} \mathrm{H}_{5}\right)_{2} \mathrm{~V}(\mathrm{CN} t-\mathrm{Bu})_{2}^{+} \mathrm{Cl}^{-}$is formed by excess tert-butyl isonitrile in near-quantitative yield ${ }^{6}$. Apparently, the relative affinities of $\mathrm{Mg}$ (II) and $\mathrm{V}$ (III) for the ligands available in these reaction systems are such that acetylacetonate is completely scavenged by $\mathrm{Mg}$ (II) while $\mathrm{V}$ (III) will take up two cyclopentadienyl and one chloride ligand.

In accord with these preferences, we find that (acac) $)_{2} \mathrm{VCl}$ reacts with the dimagnesium compound $\left(\mathrm{CH}_{3}\right)_{4} \mathrm{C}_{2}\left(\mathrm{C}_{5} \mathrm{H}_{4} \mathrm{MgCl}\right)_{2}$ (1a) to give, under substitution of the acetylacetonato ligands, the blue ansa-vanadocene monochloride 2a (Scheme 1). In situ oxidation of the latter with $\mathrm{PCl}_{3}$ affords the green dichloride $3 \mathrm{a}$ in a total yield of $79 \%$. The trisacetylacetonate $\mathrm{V}(\mathrm{acac})_{3}$ reacts with $\left(\mathrm{CH}_{3}\right)_{4} \mathrm{C}_{2}\left(\mathrm{C}_{5} \mathrm{H}_{4} \mathrm{MgCl}\right)_{2}$ (1a) to give the monochloride $\mathbf{2 a}$ in similar yields, as documented by the isolation of the diisonitrile complex $\left(\mathrm{CH}_{3}\right)_{4} \mathrm{C}_{2}\left(\mathrm{C}_{5} \mathrm{H}_{4}\right)_{2} \mathrm{~V}(\mathrm{CN} t-\mathrm{Bu})_{2}^{+} \mathrm{Cl}^{-}\left(4 \mathrm{a}^{+} \mathrm{Cl}^{-}\right)$in $75 \%$ yield upon addition of two equivalents of tert-butyl isonitrile to the product mixture.

\section{Co-Ligand Exchange Reactions}

An increased oxophilicity of the V(IV) center of the ansa-vanadocene dichloride $\left(\mathrm{CH}_{3}\right)_{4} \mathrm{C}_{2}\left(\mathrm{C}_{5} \mathrm{H}_{4}\right)_{2} \mathrm{VCl}_{2}$ (3a) - relative to the V(III) center of $2 \mathbf{a}$ - is documented by the observation that exposure to acetylacetone in water converts $\mathbf{3 a}$ to the acetylacetonato 
cation $\left(\mathrm{CH}_{3}\right)_{4} \mathrm{C}_{2}\left(\mathrm{C}_{5} \mathrm{H}_{4}\right)_{2} \mathrm{~V}(\mathrm{acac})^{+}\left(5 \mathrm{a}^{+}\right)$, which is isolated (as described for its unbridged analog ${ }^{7}$ ) by precipitation with tetraphenyl borate. Even cation $\mathbf{5 a}^{+}$, however, exchanges its acetylacetonato ligand for two $\mathrm{Cl}^{-}$ligands completely - albeit slowly - when $5 \mathrm{a}^{+} \mathrm{B}\left(\mathrm{C}_{6} \mathrm{H}_{5}\right)_{4}^{-}$is stirred with excess $\mathrm{MgCl}_{2}$ in THF solution: IR-spectrometrically, this ligand exchange reaction is found to be complete after $48 \mathrm{~h}$; after this reaction period, the dichloride complex $3 \mathrm{a}$ is quantitatively recovered. The relative oxophilicity of $\mathrm{Mg}$ (II) thus appears to exceed even that of the V(IV) center of 3a.

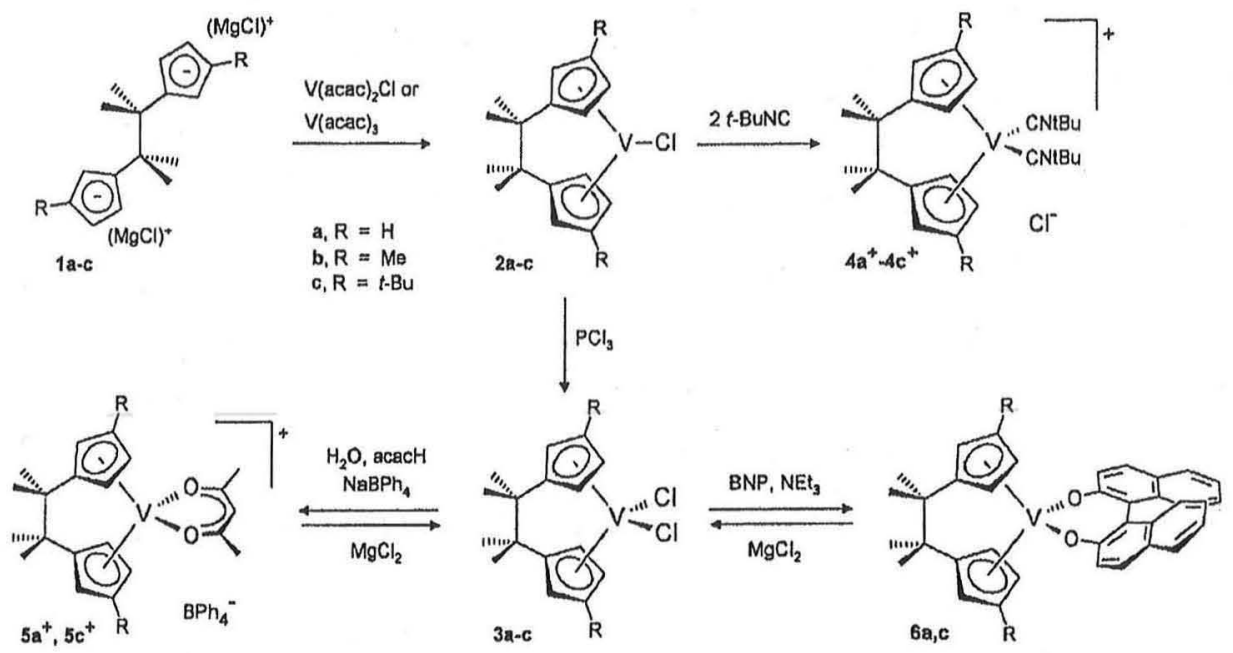

SCHEME 1

When $5 \mathbf{a}^{+} \mathrm{B}\left(\mathrm{C}_{6} \mathrm{H}_{5}\right)_{4}^{-}$is reacted with $\mathrm{MgCl}_{2}$ in the presence of the reducing agent $\left(\mathrm{Me}_{2} \mathrm{~N}\right)_{2} \mathrm{C}=\mathrm{C}\left(\mathrm{NMe}_{2}\right)_{2}$, however, the blue monochloride 2a arises instantaneously. The $\mathrm{V}(\mathrm{III})$ acetylacetonate $8 \mathbf{a}$ formed by reduction of $5 \mathbf{a}^{+} \mathrm{B}\left(\mathrm{C}_{6} \mathrm{H}_{5}\right)_{4}^{-}$thus appears much more reactive toward ligand exchange with $\mathrm{Mg}(\mathrm{II})$ : Complex $8 \mathrm{a}$, for which a high-spin $\mathrm{d}^{2}$ configuration is to be expected, is likely to bind its acetylacetonate in a monodentate manner only and is thus easily attacked by $\mathrm{MgCl}_{2}$. A similar ligand exchange occurs with 1,1'-bi-2-naphtholate: Reaction of 3a with one equivalent of binaphthol and two equivalents of triethylamine gives the ansa-vanadocene binaphtholate complex 6a; this complex is reconverted to the dichloride $3 \mathbf{a}$ by reaction with $\mathrm{MgCl}_{2}$ in THF in the course of one hour. Conversion of the dichloride 3a to the bis(triflate) complex $\left(\mathrm{CH}_{3}\right)_{4} \mathrm{C}_{2}\left(\mathrm{C}_{5} \mathrm{H}_{4}\right)_{2} \mathrm{~V}\left(\mathrm{O}_{3} \mathrm{SCF}_{3}\right)_{2}$ (7a), finally, is brought about, in analogy to the corresponding titanocene system ${ }^{8}$, by reaction with two equivalents of silver triflate in THF solution. 


\section{Chiral ansa-Vanadocene Complexes}

In order to synthesize the chiral complex $\left(\mathrm{CH}_{3}\right)_{4} \mathrm{C}_{2}\left(\mathrm{C}_{5} \mathrm{H}_{3}-3-\mathrm{Me}_{2} \mathrm{VCl}_{2}(3 \mathrm{~b})\right.$, the dimagnesium ligand salt $\mathbf{1 b}$ was reacted with $\mathrm{V}(\mathrm{acac})_{3}$ in THF solution. From this reaction, the ring-substituted ansa-vanadocene compound $\mathbf{2 b}$ arises as a mixture of meso- and racemic diastereoisomers. To determine the ratio of these diastereoisomers, typical product mixtures were converted to the diisonitrile complexes rac- and meso- $4 \mathrm{~b}^{+} \mathrm{Cl}^{-}$. The racemic and meso isomers can be distinguished by the tert-butyl signals of their isonitrile ligands, which are homotopic for the racemic complex and diastereotopic for the meso isomer. A rac/meso ratio of close to $1: 1$ was thus obtained. In this case, we were not able to separate the diastereomers. Oxidation of the product mixture with $\mathrm{PCl}_{3}$ gave the dichloride $\mathbf{3 b}$ as a mixture of rac and meso diastereomers in a total yield of $76 \%$.

For the synthesis of the tert-butyl substituted complex $\left(\mathrm{CH}_{3}\right)_{4} \mathrm{C}_{2}\left(\mathrm{C}_{5} \mathrm{H}_{3}-3-t-\mathrm{Bu}\right)_{2} \mathrm{VCl}_{2}$ (3c), reactions of the corresponding dimagnesium ligand salt $1 \mathrm{c}$ with a number of different vanadium(III) starting compounds were conducted at various temperatures and the ensuing rac/meso ratios studied by conversion of the respective product mixtures to the diamagnetic diisonitrile complexes rac- and meso-4c $\mathrm{c}^{+} \mathrm{Cl}^{-}$(Table I). Higher rac/meso ratios $(6: 1)$ were achieved with $\mathrm{V}(\mathrm{acac})_{3}$ than with $\mathrm{V}(\mathrm{acac})_{2} \mathrm{Cl}$ or $\mathrm{VCl}_{3}$ as starting materials. With $\mathrm{V}(\text { acac })_{2} \mathrm{Cl}$, higher reaction temperatures led to a stronger preference for the racemic product, as previously observed in other cases ${ }^{9}$. With the chiral reactant tris $(R, S$-hydroxymethylene camphorate) $\mathrm{V}$ (III), rac-3c was again the preferred product, but with a rac/meso ratio of only $3.5: 1$. Oxidation of the tert-butyl substituted monochloride complex $2 \mathrm{c}$ with $\mathrm{PCl}_{3}$ proved to be very sluggish; in this case, oxidation of the product mixture with $\mathrm{AgCl}$ gave the dichloride $3 \mathrm{c}$ in the course of $12 \mathrm{~h}$ in a yield of $74 \%$.

TABLE I

Yields and rac/meso ratios for compound $3 \mathrm{c}$

\begin{tabular}{lccc}
\hline \multicolumn{1}{c}{ Reactant } & Temperature, ${ }^{\circ} \mathrm{C}$ & Yield, $\%$ & rac/meso \\
\hline $\mathrm{VCl}_{3}(\mathrm{THF})_{3}$ & -78 & 38 & $1 / 1$ \\
$\mathrm{VCl}_{3}(\mathrm{THF})_{3}$ & 20 & 35 & $3 / 1$ \\
$\mathrm{VCl}_{3}(\mathrm{THF})_{3}$ & 65 & 34 & $4 / 1$ \\
$(\mathrm{acac})_{2} \mathrm{VCl}(\mathrm{THF})$ & -78 & 61 & $1 / 1.3$ \\
$(\mathrm{acac})_{2} \mathrm{VCl}(\mathrm{THF})$ & 20 & 62 & $3 / 1$ \\
$(\mathrm{acac})_{2} \mathrm{VCl}(\mathrm{THF})$ & 65 & 61 & $5 / 1$ \\
$\mathrm{~V}(\mathrm{acac})_{3}$ & 20 & 59 & $6 / 1$ \\
\end{tabular}


Finally, complex $3 c$ was also converted to the red binaphtholate derivative $6 \mathrm{c}$ by reaction with rac-1,1'-bi-2-naphthol and triethylamine. After chromatography on silanized silica gel, complex $6 \mathrm{c}$ was isolated in $\mathrm{ca} 70 \%$ yield. Reduction with tetrakis $(N, N$ dimethylamino)ethylene and conversion to the diisonitrile complex $4 \mathrm{c}^{+} \mathrm{Cl}^{-}$showed that only the racemic binaphtholate derivative, rac-6c, was obtained. The fate of the meso isomer remains to be clarified; conceivable are either its conversion to the racemic isomer during complex formation with the binaphtholate anion or its irreversible fixation to the chromatography column.

Reaction of complex $3 \mathrm{c}$ with one half equivalent of $(R)-(+)$-binaphthol and one equivalent of triethylamine and subsequent removal of unreacted dichloride $3 \mathrm{c}$ by chromatography on silanized silica gel afforded an optically active binaphtholate complex, presumably the isomer of $6 \mathrm{c}$ with $1-R$ configuration at the bridgehead carbon atom, in which the tert-butyl groups are farthest from the binaphtholate ligands. Rather than by chromatography, unreacted dichloride $S-3$ c can also be removed from the product mixture by its selective conversion to the acetylacetonate cation upon extraction with water and acetylacetone. The tetraphenylborate of the acetylacetonato complex, $5 \mathbf{a}^{+} \mathrm{B}\left(\mathrm{C}_{6} \mathrm{H}_{5}\right)_{4}^{-}$,

FIC. 1

Crystal structure of complex $2 a$

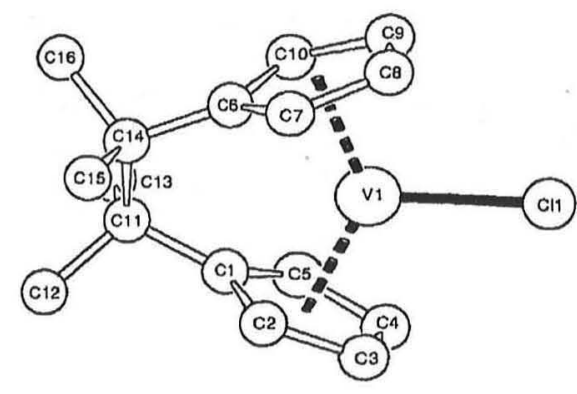

FIG. 2

Structure of cation $4 \mathrm{a}^{+}$in crystalline $4 \mathrm{a}^{+} \mathrm{Cl}^{-}$

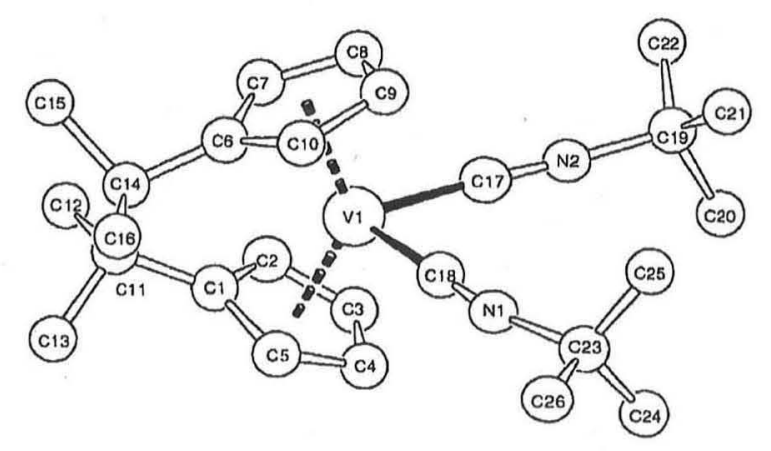


was thus obtained in form of green crystals suitable for a diffractometric structure determination.

The bis(triflate) complexes $7 \mathrm{a}$ and $R-7 \mathrm{c}$ (obtained from the chiral dichloride $R-3 \mathrm{c}$ in a manner analogous to that described above for $7 \mathbf{a})$ proved to be useful catalysts for Lewis-acid induced Diels-Alder and other $\mathrm{C}-\mathrm{C}$ coupling reactions; these observations are to be reported in a separate communication.

\section{Crystal Structures}

The molecular structures of complexes $2 \mathbf{a}, 4 \mathbf{a}^{+} \mathrm{Cl}^{-}, 5 \mathbf{a}^{+} \mathrm{B}\left(\mathrm{C}_{6} \mathrm{H}_{5}\right)_{4}^{-}$and $5 \mathbf{c}^{+} \mathrm{B}\left(\mathrm{C}_{6} \mathrm{H}_{5}\right)_{4}^{-}$were determined by crystal structure analysis (Figs $1-4$ ). Characteristic bond lengths and angles are summarized in Tables II and III.
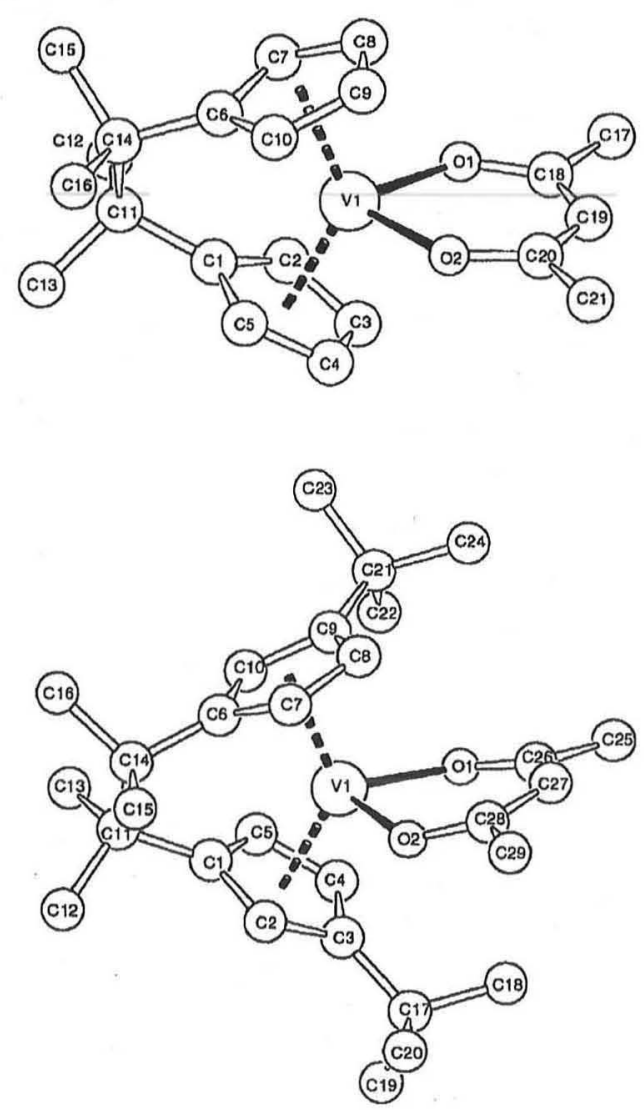

FIG. 3

Structure of cation $5 \mathrm{a}^{+}$in crystalline $5 \mathrm{a}^{+} \mathrm{B}\left(\mathrm{C}_{6} \mathrm{H}_{5}\right)_{4}^{-}$

FIO. 4

Structure of cation $5 \mathrm{c}^{+}$in crystalline $5 \mathrm{c}^{+} \mathrm{B}\left(\mathrm{C}_{6} \mathrm{H}_{5}\right)_{4}^{-}$ 
In the vanadium(III)-monochloro complex $\mathbf{2 a}$, the $\mathrm{VCl}$ distance is about $7 \mathrm{ppm}$ shorter than in the dichloro complex 3a. The vanadium-Cp-centroid distance is likewise shortened by ca $3 \mathrm{pm}$. As in the corresponding unbridged vanadocene mono- and di-

TABLLE II

Selected bond distances (ppm) and angles $\left({ }^{\circ}\right)$ for complex $2 \mathrm{a}$ and of the cation $4 \mathrm{a}^{+}$in crystalline $4 \mathrm{a}^{+} \mathrm{Cl}^{-}$

\begin{tabular}{|c|c|c|c|}
\hline Atoms & Distances, angles & Atoms & Distances, angles \\
\hline \multicolumn{2}{|c|}{$2 a$} & \multicolumn{2}{|c|}{$4 a^{+}$} \\
\hline $\mathrm{V} 1-\mathrm{Cl}$ & $238.0(1)$ & $\mathrm{V} 1-\mathrm{C} 17$ & $202.4(14)$ \\
\hline $\mathrm{V} 1-\mathrm{Cl}$ & $226.4(3)$ & $\mathrm{V} 1-\mathrm{C} 18$ & $195.8(14)$ \\
\hline $\mathrm{V} 1-\mathrm{C} 2$ & $226.0(4)$ & $\mathrm{VI}-\mathrm{Cl}$ & $226.2(13)$ \\
\hline $\mathrm{V} 1-\mathrm{C} 3$ & $227.9(4)$ & $\mathrm{V} 1-\mathrm{C} 2$ & $226.5(15)$ \\
\hline $\mathrm{VI}-\mathrm{C} 4$ & $228.5(4)$ & V $1-C 3$ & $230.4(16)$ \\
\hline V1-C5 & $227.8(4)$ & $\mathrm{VI}-\mathrm{C} 4$ & $224.6(1.3)$ \\
\hline V1-C6 & $227.0(4)$ & $\mathrm{V} 1-\mathrm{C} 5$ & $221.3(14)$ \\
\hline V1-C7 & $227.3(4)$ & $\mathrm{V} 1-\mathrm{C} 6$ & $\overline{222.3(13)}$ \\
\hline V1-C8 & $227.5(4)$ & V1-C7 & $229.3(1.3)$ \\
\hline VI-C9 & $227.3(4)$ & $\mathrm{V} 1-\mathrm{C} 8$ & $230.8(14)$ \\
\hline $\mathrm{V} 1-\mathrm{C} 10$ & $226.1(4)$ & $\mathrm{V} 1-\mathrm{C} 9$ & $224.1(14)$ \\
\hline V1-CCR $1^{\prime \prime}$ & 193.2 & $\mathrm{~V} 1-\mathrm{C} 10$ & $222.1(14)$ \\
\hline \multirow[t]{2}{*}{ V1-CR2 ${ }^{a}$} & 192.8 & $\mathrm{C} 17-\mathrm{N} 2$ & $114.3(18)$ \\
\hline & & $\mathrm{C} 18-\mathrm{N} 1$ & $116.6(18)$ \\
\hline CR1-V-CR2 ${ }^{\prime \prime}$ & 136.7 & $\mathrm{C} 19-\mathrm{N} 2$ & $148.0(16)$ \\
\hline \multirow[t]{8}{*}{$\mathrm{CP} 1-\mathrm{CP}_{2}{ }^{b}$} & 44.6 & $\mathrm{C} 23-\mathrm{N} 1$ & $150.1(19)$ \\
\hline & & VI-CR1". & 191.7 \\
\hline & & V1-CR2" & 191.7 \\
\hline & & $\mathrm{CR} 1-\mathrm{V} 1-\mathrm{CR} 2^{\prime \prime}$ & 134.2 \\
\hline & & $\mathrm{C} 17-\mathrm{V} 1-\mathrm{C} 18$ & $82.4(6)$ \\
\hline & & $\mathrm{C} 17-\mathrm{N} 2-\mathrm{C} 19$ & $172.0(13)$ \\
\hline & & $\mathrm{C} 18-\mathrm{N} 1-\mathrm{C} 23$ & $167.3(13)$ \\
\hline & & $\mathrm{CP} 1-\mathrm{CP} 2^{\prime \prime}$ & 46.6 \\
\hline
\end{tabular}

" CR1, CR2 centroids of C atoms numbered $1-5$ and 6-10, respectively. " CP1, CP2 mean planes of corresponding $\mathrm{C}_{5}$ rings. 
chlorides ${ }^{10}$, the decreased VCl bond distance is likely to result from the reduced coordination number. Due to the shortened centroid-vanadium distances, the bridgeheadbridgehead distance is only about $268 \mathrm{pm}$. As a consequence, the centroid-V-centroid angle is widened by $\mathrm{ca} 6^{\circ}$ relative to that in the dichloride $3 \mathrm{a}$. The $\mathrm{V}-\mathrm{Cl}$ bond deviates by only $3^{\circ}$ from the $C_{2}$-axis of the ligand framework.

The centroid-V-centroid angle in the diamagnetic vanadium(III) cation $\mathbf{4 a}^{+}$is intermediate between that of the monochloride $2 \mathbf{a}$ and the dichloride $3 \mathbf{a}$. The $\mathrm{V}$-centroid

TABLE III

Selected bond distances $(\mathrm{ppm})$ and angles $\left(^{\circ}\right)$ for cationic complexes $\mathbf{5 \mathbf { a } ^ { + }}$ and $\mathbf{5 \mathbf { c } ^ { * }}$ in their crystalline $\mathrm{BPh}_{4}^{-}$salts

\begin{tabular}{|c|c|c|c|}
\hline Atoms & Distances, angles & Atoms & Distances, angles \\
\hline \multicolumn{2}{|c|}{$5 a^{+}$} & \multicolumn{2}{|c|}{$5 c^{+}$} \\
\hline VI-OI & $201.5(4)$ & V1-OI & $199.7(3)$ \\
\hline $\mathrm{V} 1-\mathrm{O} 2$ & $201.0(3)$ & $\mathrm{V} 1-\mathrm{O} 2$ & $200.8(3)$ \\
\hline $\mathrm{V} 1-\mathrm{Cl}$ & $228.8(5)$ & $\mathrm{V} 1-\mathrm{Cl}$ & $230.0(4)$ \\
\hline $\mathrm{V} 1-\mathrm{C} 2$ & $223.9(5)$ & $\mathrm{V} 1-\mathrm{C}_{2}$ & $230.9(4)$ \\
\hline $\mathrm{V} 1-\mathrm{C} 3$ & $226.2(6)$ & $\mathrm{V} 1-\mathrm{C} 3$ & $238.3(4)$ \\
\hline $\mathrm{V} 1-\mathrm{C} 4$ & $232.2(7)$ & $\mathrm{V} 1-\mathrm{C} 4$ & $232.8(4)$ \\
\hline $\mathrm{VI}-\mathrm{C} 5$ & $228.5(6)$ & $\mathrm{V} 1-\mathrm{C} 5$ & $228.7(4)$ \\
\hline V1-C6 & $229.2(5)$ & $\mathrm{V} 1-\mathrm{C} 6$ & $227.4(5)$ \\
\hline $\mathrm{V} 1-\mathrm{C} 7$ & $228.1(5)$ & $\mathrm{V} 1-\mathrm{C7}$ & $227.1(4)$ \\
\hline $\mathrm{V} 1-\mathrm{C} 8$ & $231.4(5)$ & V1-C8 & $231.6(5)$ \\
\hline $\mathrm{V} 1-\mathrm{C} 9$ & $228.5(5)$ & $\mathrm{V} 1-\mathrm{C} 9$ & $240.3(5)$ \\
\hline $\mathrm{V} 1-\mathrm{C} 10$ & $224.2(5)$ & $\mathrm{VI}-\mathrm{ClO}$ & $231.9(5)$ \\
\hline $\mathrm{C} 18-\mathrm{O} 1$ & $127.7(7)$ & $\mathrm{C} 26-\mathrm{OI}$ & $127.3(6)$ \\
\hline $\mathrm{C} 2 \mathrm{O}-\mathrm{O} 2$ & $127.4(6)$ & $\mathrm{C} 28-\mathrm{O} 2$ & $128.0(6)$ \\
\hline $\mathrm{V} 1-\mathrm{CR} \mathrm{I}^{\prime \prime}$ & 194.4 & $\mathrm{~V}|-\mathrm{CR}|^{\prime \prime}$ & 198.4 \\
\hline $\mathrm{V} 1-\mathrm{CR} 2^{\prime \prime}$ & 194.7 & $\mathrm{~V} 1-\mathrm{CR} 2^{\prime \prime}$ & 197.8 \\
\hline CRI-V-CR2" & 131.9 & $\mathrm{CR} 1-\mathrm{V}-\mathrm{CR} 2^{\prime \prime}$ & 13() .1 \\
\hline $\mathrm{O} 1-\mathrm{V} 1-\mathrm{O} 2$ & $86.5(1)$ & $\mathrm{O} 1-\mathrm{V} 1-\mathrm{O} 2$ & $86.3(1)$ \\
\hline $\mathrm{CP} 1-\mathrm{CP} 2^{b}$ & 49.3 & $\mathrm{CP} 1-\mathrm{CP} 2^{\prime \prime}$ & 53.4 \\
\hline
\end{tabular}

"CR1, CR2 centroids of C atoms numbered 1-5 and 6-10, respectively. "CP1, CP2 mean planes of corresponding $\mathrm{C}_{5}$ rings. 
distance of $191 \mathrm{pm}$ is shorter here than in any of the other vanadium complexes studied. The bisector of the diisonitrile vanadium fragment deviates by $21^{\circ}$ from the $C_{2}$ axis of the ligand fragment; distortions of this kind were previously observed also in other ansa-metallocene complexes ${ }^{11}$.

In the vanadium(IV)acetylacetonato cation $5 \mathbf{a}^{+}$, bond distances and angles of the ligand framework are similar to those in the dichloride ${ }^{3} 3 \mathrm{a}$. The acetylacetonato ligand is practically planar; its geometry is comparable to those of other vanadium(IV) acetylacetonato compounds ${ }^{12}$. The bisector of the $\mathrm{V}(\mathrm{acac})$ fragment deviates from the $C_{2}$ axis of the ligand framework by only $7^{\circ}$, compared to a deviation of $16^{\circ}$ for the $\mathrm{VCl}_{2}$ fragment in the dichloro complex ${ }^{3} 3 \mathbf{a}$.

The geometry of the cation $5 \mathrm{c}^{+}$, finally, documents the racemic configuration of this tert-butyl substituted ansa-vanadocene complex. Compared to its unsubstituted analog $5 \mathbf{a}^{+}$, the $\mathrm{V}(\mathrm{acac})$ fragment deviates from the $C_{2}$ axis of the ligand framework by a substantially larger angle of $\mathrm{ca} 20^{\circ}$; this is undoubtedly caused by the increased steric interactions. As generally observed with related metallocene structures, the metal-centroid distances are also increased by introduction of the bulky ring substituents.

\section{EXPERIMENTAL}

General

Moisture- and air-sensitive compounds were handled under an argon atmosphere using Schlenk techniques. THF and diethyl ether were distilled from sodium benzophenone ketyl, pentane from $\mathrm{CaH}_{2}$. NMR spectra were recorded on Bruker WM-250 and Bruker AC-250 FT spectrometers. (acac) $)_{2} \mathrm{VCI}(\mathrm{THF})\left(\right.$ ref. $\left.^{13}\right), \mathrm{V}(\mathrm{acac})_{3}\left(\right.$ ref. $\left.^{14}\right)$ and $\left(\mathrm{CH}_{3}\right)_{4} \mathrm{C}_{2}\left(\mathrm{C}_{5} \mathrm{H}_{3} \mathrm{R}\right)_{2}(\mathrm{MgCl})_{2}(\mathrm{THF})_{4}(\mathrm{R}=\mathrm{H}, \mathrm{Me}, t-\mathrm{Bu})$ $\left(\right.$ refs $\left.^{2,15,16}\right)$ were prepared as described in the literature.

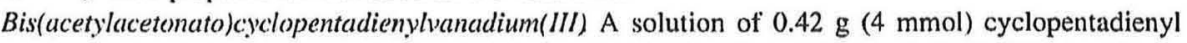
potassium dissolved in $50 \mathrm{ml}$ THF was slowly added to $0.71 \mathrm{~g}(2 \mathrm{mmol})$ (acac) ${ }_{2} \mathrm{VCl}(\mathrm{THF})$ in $150 \mathrm{ml}$ THF. After stirring the reaction mixture for $16 \mathrm{~h}$ at room temperature, the precipitated potassium chloride was removed by filtration. The filtrate was freed from solvent in vacuo and the remaining solid taken up in $50 \mathrm{ml}$ ether. After filtration, the solution was concentrated to a small volume, $30 \mathrm{ml}$ of pentane were added and the mixture cooled to $-80^{\circ} \mathrm{C}$. The brown precipitate was isolated by filtration and dried in vacuo to give $440 \mathrm{mg}$ (ca $70 \%$ yield) of a brown air-sensitive powder consisting of essentially pure $\mathrm{CpV}(\mathrm{acac})_{2}$, which presumably still contains a small amount of (acac) ${ }_{2} \mathrm{VCl}(\mathrm{THF})$ as judged by its IR spectrum. IR spectrum (Nujol, $\mathrm{KBr}, \mathrm{cm}^{-1}$ ): 3079 (w), 1576 (s), 1521 (s), 1457 (s), $1424(\mathrm{~m}), 1420(\mathrm{~m}), 1381(\mathrm{~s}), 1364(\mathrm{~s}), 1275(\mathrm{~m}), 1018(\mathrm{~m}), 931(\mathrm{w}), 798(\mathrm{~m})$. Mass spectrum $\left(\mathrm{El}, 70 \mathrm{eV}, 50{ }^{\circ} \mathrm{C}\right), \mathrm{C}_{10} \mathrm{H}_{19} \mathrm{OV}(314 \mathrm{~g} / \mathrm{mol}): \mathrm{m} / \mathrm{z}, 348\left(\mathrm{~V}\left(\mathrm{C}_{5} \mathrm{H}_{7} \mathrm{O}_{2}\right), 3 \%\right), 314\left(\mathrm{M}^{+}, 26 \%\right), 249\left(\mathrm{M}^{+}-\right.$ $\left.\mathrm{C}_{5} \mathrm{H}_{5}, 100 \%\right), 215\left(\mathrm{M}^{+}-\mathrm{C}_{5} \mathrm{H}_{7} \mathrm{O}_{2}, 3 \%\right), 166\left(\mathrm{M}^{+}-\mathrm{C}_{5} \mathrm{H}_{5}-\mathrm{C}_{5} \mathrm{H}_{8} \mathrm{O}, 37 \%\right)$.

Tetramethylethanediylbis(cyclopentadienyl)vanadium dichloride (3a). To $0.71 \mathrm{~g}$ (2 mmol) (acac) $)_{2} \mathrm{VCl}(\mathrm{THF})$ in $60 \mathrm{ml} \mathrm{THF} ; 2 \mathrm{mmol}$ of $\left(\mathrm{CH}_{3}\right)_{4} \mathrm{C}_{2}\left(\mathrm{C}_{5} \mathrm{H}_{4}\right)_{2}(\mathrm{MgCl})_{2}(\mathrm{THF})_{4}$ (1a) dissolved in $100 \mathrm{ml}$ THF were slowly added. After stirring the reaction mixture for $20 \mathrm{~h}$, the solvent was removed in vacuo. The residue was taken up in ether and the resulting blue suspension filtered to remove insoluble inorganic products. From the filtrate, $\left(\mathrm{CH}_{3}\right)_{4} \mathrm{C}_{2}\left(\mathrm{C}_{5} \mathrm{H}_{4}\right)_{2} \mathrm{VCl}$ (2a) was obtained as an air-sensitive blue solid. IR spectrum (Nujol, $\mathrm{KBr}$ ): 3079 (w), 1452 (m), I 043 (w), 804, 795 (s) $\mathrm{cm}^{-1}$. Mass spectrum (El, $\left.70 \mathrm{eV}, 170^{\circ} \mathrm{C}\right), \mathrm{C}_{16} \mathrm{H}_{20} \mathrm{VCl}(298.7 \mathrm{~g} / \mathrm{mol}): \mathrm{m} / 2298\left(\mathrm{M}^{+}, 54 \%\right), 258\left(\mathrm{M}-\mathrm{C}_{3} \mathrm{H}_{4}, 45 \%\right), 192$ 
$\left(\mathrm{M}^{+}-\mathrm{C}_{8} \mathrm{H}_{10}, 23 \%\right), 156\left(\mathrm{M}^{+}-\mathrm{HCl}-\mathrm{C}_{8} \mathrm{H}_{10}, 100 \%\right)$. Alternatively, the filtrate, which contained the monochloride $2 \mathrm{a}$, was oxidized with $0.17 \mathrm{ml}(2 \mathrm{mmol})$ of $\mathrm{PCl}_{3}$ to the green ansa-vanadocene dichloride 3a which precipitated and was isolated by filtration. The green solid was dissolved in $20 \mathrm{ml}$ methylene chloride, filtered and the filtrate concentrated to a small volume (cal-2 ml). Ether (40 $\mathrm{ml}$ ) was added and the resulting suspension cooled to $-30^{\circ} \mathrm{C}$. The green solid was collected by filtration and dried in vacuo to yield $528 \mathrm{mg}(79 \%)\left(\mathrm{CH}_{3}\right)_{4} \mathrm{C}_{2}\left(\mathrm{C}_{5} \mathrm{H}_{4}\right)_{2} \mathrm{VCl}_{2}$ (3a). IR spectrum (Nujol, $\mathrm{KBr}): 3093$ (w), 1420 (m), 1051 (w), 823 (s). For $\mathrm{C}_{16} \mathrm{H}_{20} \mathrm{Cl}_{2} \mathrm{~V}$ (334.2) calculated: $57.51 \% \mathrm{C}$ $6.03 \% \mathrm{H}$; found: $58.04 \% \mathrm{C}, 6.23 \% \mathrm{H}$. Mass spectrum (El, $\left.70 \mathrm{eV}, 250{ }^{\circ} \mathrm{C}\right): \mathrm{m} / \mathrm{z} 333\left(\mathrm{M}^{+}, 15 \%\right), 298$ $\left(\mathrm{M}^{+}-\mathrm{Cl}, 22 \%\right), 258\left(\mathrm{M}^{+}-\mathrm{Cl}-\mathrm{C}_{3} \mathrm{H}_{4}, 19 \%\right), 191\left(\mathrm{M}^{+}-\mathrm{Cl}-\mathrm{C}_{4} \mathrm{H}_{10}, 100 \%\right), 156\left(\mathrm{M}^{+}-2 \mathrm{Cl}-\mathrm{C}_{9} \mathrm{H}_{10}, 45 \%\right)$

Tetramethylethanediylbis(cyclopentadienyl)vanadiumbis(t-butylisonitrile) chloride $\left(\mathbf{4 a}^{+} \mathrm{Cl}^{-}\right)$. To $0.97 \mathrm{~g}(2.8 \mathrm{mmol}) \mathrm{V}(\mathrm{acac})_{3}$ in $100 \mathrm{ml}$ THF were added dropwise $2.8 \mathrm{mmol}$ of the magnesium ligand salt 1a, dissolved in $100 \mathrm{ml}$ THF. After stirring the mixture for $24 \mathrm{~h}$ at room temperature, the solvent was removed in vacuo. The residue was taken up in $200 \mathrm{ml}$ of ether and filtered. On addition of $0.63 \mathrm{ml}$ ( $4.6 \mathrm{mmol}$ ) of 1 -butylisonitrile to the filtrate, the color changed from blue to brown and the brown product $4 \mathrm{a}^{+} \mathrm{Cl}^{-}$precipitated. The solid was isolated by filtration and recrystallization from $\mathrm{CH}_{2} \mathrm{Cl}_{2}$-ether to yield $0.98 \mathrm{~g}\left[\left(\mathrm{CH}_{3}\right)_{4} \mathrm{C}_{2}\left(\mathrm{C}_{5} \mathrm{H}_{4}\right)_{2} \mathrm{~V}\left(\mathrm{C}_{4} \mathrm{H}_{9} \mathrm{NC}\right)_{2}\right] \mathrm{Cl}\left(4 \mathrm{a}^{+} \mathrm{Cl}^{-}\right)\left(75 \%\right.$ yield). IR spectrum (Nujol, $\left.\mathrm{KBr}, \mathrm{cm}^{-1}\right)$ :

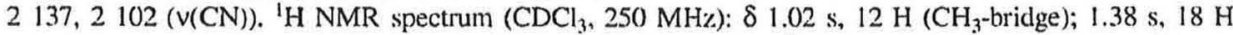
$\left(\mathrm{C}\left(\mathrm{CH}_{3}\right)_{3}-\mathrm{NC}\right) ; 5.0 \mathrm{~m}, 4 \mathrm{H}\left(\beta-\mathrm{C}_{5} \mathrm{H}_{4}\right) ; 5.13 \mathrm{~m}, 4 \mathrm{H}\left(\alpha-\mathrm{C}_{5} \mathrm{H}_{4}\right)$. The ' $\mathrm{H}$ NMR signals of $\alpha$ and $\beta$ cyclopentadienyl protons of these complexes were assigned by means of a ROESY experiment; as in other metallocene complexes with 18-electron contiguration ${ }^{2.17}$, the protons in $\alpha$-position are shifted to lower fields than those in $\beta$-position. ${ }^{13} \mathrm{C}$ NMR spectrum (63 $\left.\mathrm{MH} \%, \mathrm{CDCl}_{3}\right): \delta 27.33\left(\mathrm{C}_{3} \mathrm{CH}_{3}\right)_{2}$-bridge); $30.39\left(\left(\mathrm{CH}_{3}\right)_{3} \mathrm{C}-\mathrm{NC}\right) ; 44.65$ $\left(\mathrm{C}\left(\mathrm{CH}_{3}\right)_{2}\right.$-bridge); $58.91\left(\left(\mathrm{CH}_{3}\right)_{3} \mathrm{C}-\mathrm{NC}\right) ; 86.60\left(\alpha-\mathrm{C}_{5} \mathrm{H}_{4}\right) ; 98.26\left(\beta-\mathrm{C}_{5} \mathrm{H}_{4}\right) ; 128.89$ (bridgehead- $\left.(1)-\mathrm{C}_{5} \mathrm{H}_{4}\right)$. For $\mathrm{C}_{26} \mathrm{H}_{3 \mathrm{~B}} \mathrm{CINV}(465.0)$ calculated: $6.02 \% \mathrm{~N}, 8.24 \% \mathrm{H}$; found: $6.09 \% \mathrm{~N}, 8.26 \% \mathrm{H}$.

Tetramethylethanedivlbis(cyclopentadienyl)acetylacetonatovanadium tetraphenylborate $\left(5 \mathrm{a}^{+} \mathrm{B}\left(\mathrm{C}_{6} \mathrm{H}_{5}\right)_{4}\right)$. Compound $\left(\mathrm{CH}_{3}\right)_{4} \mathrm{C}_{2}\left(\mathrm{C}_{5} \mathrm{H}_{4}\right)_{2} \mathrm{VCl}_{2}$ (3a) $(150 \mathrm{mg}, 0.45 \mathrm{mmol})$ was suspended in $20 \mathrm{ml} \mathrm{H}_{2} \mathrm{O}$. On addition of $90 \mathrm{mg}$ acetylacetone $(0.91 \mathrm{mmol})$, the solid dissolved and the color changed from green to brown. After stirring for one hour at room temperature, the reaction mixture was filtered and the filtrate, which contained the cation $\left[\left(\mathrm{CH}_{3}\right)_{4} \mathrm{C}_{2}\left(\mathrm{C}_{5} \mathrm{H}_{4}\right)_{2} \mathrm{~V}\left(\mathrm{C}_{5} \mathrm{H}_{7} \mathrm{O}_{2}\right)\right]^{+}\left(5 \mathrm{a}^{+}\right)$, mixed with $170 \mathrm{mg}(0.5 \mathrm{mmol})$ $\mathrm{Na}\left(\mathrm{B}\left(\mathrm{C}_{6} \mathrm{H}_{5}\right)_{4}\right)$ in $10 \mathrm{ml}$ water to precipitate an olive green solid. This was collected by filtration and washed with water. Coevaporation of the green powder with toluene and drying in vacuo gave $260 \mathrm{mg}$ $\left[\left(\mathrm{CH}_{3}\right)_{4} \mathrm{C}_{2}\left(\mathrm{C}_{5} \mathrm{H}_{42} \mathrm{~V}\left(\mathrm{C}_{5} \mathrm{H}_{7} \mathrm{O}_{2}\right)\right] \mathrm{B}\left(\mathrm{C}_{6} \mathrm{H}_{5}\right)_{4}\left(5 \mathrm{a}^{+} \mathrm{B}\left(\mathrm{C}_{6} \mathrm{H}_{5}\right)_{4}^{-}\left(85 \%\right.\right.\right.$ yield). IR spectrum (Nujol, $\left.\mathrm{KBr}, \mathrm{cm}^{-1}\right): 3107$ (w), 3050 (m), 3037 (w), 3025 (m), 1582 (s), 1561 (s), 1521 (s), 1512 (s), 1463 (s), $1426(\mathrm{w}), 1344$ (w), $1279(w), 1147(w), 1031$ (w), $935(w), 846(w), 831(\mathrm{~m}), 744(\mathrm{~m}), 736(\mathrm{~m}), 728(\mathrm{~m})$. For $\mathrm{C}_{45} \mathrm{H}_{47} \mathrm{BO}_{2} \mathrm{~V}(681.6)$ calculated: $79.3 \% \mathrm{C}, 6.95 \% \mathrm{H}$; found: $79.53 \% \mathrm{C}, 7.05 \% \mathrm{H}$.

Tetranethylethanediylbis(cyclopentadienyl)vanadium binaphtholate (6a). To al solution of $0.47 \mathrm{~g}$ ( $1.41 \mathrm{mmol})\left(\mathrm{CH}_{3}\right)_{4} \mathrm{C}_{2}\left(\mathrm{C}_{5} \mathrm{H}_{4}\right)_{2} \mathrm{VCl}_{2}$ (3a) and $0.4 \mathrm{~g}(1.41 \mathrm{mmol})$ binaphthol in $50 \mathrm{ml}$ THF were added ().39 $\mathrm{ml}(2.81 \mathrm{mmol})$ of triethylamine in one portion. After stirring for one hour, the green solution slowly turned red. Alter stirring for $14 \mathrm{~h}$. THF was exchanged for toluene. The colorless precipitate was removed by filtration and the solution filtered over a small plug of silylated silica gel. The filtrate was evaporated in vacuo, the residue suspended in a small volume of ether and cooled to $-30{ }^{\circ} \mathrm{C}$. The red orange solid was isolated by filtration and dried in vacuos to give $0.66 \mathrm{gg}(86 \%)$ $\left(\mathrm{CH}_{3}\right)_{4} \mathrm{C}_{2}\left(\mathrm{C}_{5} \mathrm{H}_{4}\right)_{2} \mathrm{~V}\left(\mathrm{C}_{20} \mathrm{H}_{12} \mathrm{O}_{2}\right)$ (6a). IR spectrum (Nujol, $\left.\mathrm{KBr}, \mathrm{cm}^{-1}\right): 3107$ (w), 3 (083 (w), 1610 (w), 1587 (w), I $499(\mathrm{w}), 1354(\mathrm{~m}), 1277(\mathrm{~m}), 12469 \mathrm{~s}), \mathrm{I} 124(\mathrm{~m}), 1(071(\mathrm{~m}), 826$ \%s), $8179 \mathrm{~s}), 745(\mathrm{~m})$. For $\mathrm{C}_{44} \mathrm{H}_{48} \mathrm{O}_{2} \mathrm{~V}(547.8)$ calculated: $78.94 \% \mathrm{C}, 5.89 \% \mathrm{H}$; found: $78.13 \% \mathrm{C}, 6.01 \% \mathrm{H}$. Mass spectrum $\left(\mathrm{El}, 70 \mathrm{eV}, 280{ }^{\circ} \mathrm{C}\right): \mathrm{m} / \mathrm{z} 547\left(\mathrm{M}^{+}, 13 \%\right), 412\left(\mathrm{M}^{+}-\mathrm{C}_{8} \mathrm{H}_{10}, 2 \%\right), 335\left(\mathrm{M}^{+}-\mathrm{C}_{16} \mathrm{H}_{19}, 10 \%\right), 261\left(\mathrm{M}^{+}-\right.$ $\left.\mathrm{C}_{20} \mathrm{H}_{14} \mathrm{O}_{2} \mathrm{~V}, 100 \%\right)$.

Tetramethylethanedislbis(cyclopentadienyl)vanadium bistriflate (7a). $0.23 \mathrm{~g}(0.69 \mathrm{mmol})$ of the ansc-vanadocene dichloride $3 \mathrm{a}$ and $0.35 \mathrm{~g}(1.38 \mathrm{mmol})$ silver triflate were mixed and $50 \mathrm{ml}$ of THF 
added. After $10 \mathrm{~h}$ the precipitated silver chloride was removed by filtration and the filtrate evaporated to dryness. The residue was recrystallized twice from $\mathrm{CH}_{2} \mathrm{Cl}_{2}$-ether mixture to give $0.3 \mathrm{~g}$ $\left(\mathrm{CH}_{3}\right)_{4} \mathrm{C}_{2}\left(\mathrm{C}_{5} \mathrm{H}_{4}\right)_{2} \mathrm{~V}\left(\mathrm{O}_{3} \mathrm{SCF}_{3}\right)_{2}(7 \mathrm{a})$ as a blue-green powder in $78 \%$ yield. IR spectrum (Nujol, $\left.\mathrm{KBr}, \mathrm{cm}^{-1}\right): 3123(\mathrm{w})$, 1454 (w), $1327(\mathrm{~m}), 1284(\mathrm{w}), 1232(\mathrm{~m}), 1206(\mathrm{~s}), 1191(\mathrm{~s}), 1090(\mathrm{~m}), 1(\mathrm{l}) 1(\mathrm{~s}), 1020(\mathrm{~m}), 860(\mathrm{w})$, $845(\mathrm{w}), 801(\mathrm{w})$. For $\mathrm{C}_{18} \mathrm{H}_{20} \mathrm{~F}_{6} \mathrm{O}_{6} \mathrm{~S}_{2} \mathrm{~V}(561.4)$ calculated: $38.51 \% \mathrm{C}, 3.59 \% \mathrm{H}$; found: $38.21 \% \mathrm{C}$, $3.73 \% \mathrm{H}$. Mass spectrum $\left(\mathrm{El}, 70 \mathrm{eV}, 220{ }^{\circ} \mathrm{C}\right): \mathrm{m} / 2561\left(\mathrm{M}^{+}, 31 \%\right), 412\left(\mathrm{M}^{+}-\mathrm{SO}_{3} \mathrm{CF}_{3}, 70 \%\right), 305$ $\left(\mathrm{M}^{+}-\mathrm{SO}_{3} \mathrm{CF}_{3}-\mathrm{C}_{8} \mathrm{H}_{11}, 100 \%\right), 261\left(\mathrm{M}^{+}-2 \mathrm{HSO}_{3} \mathrm{CF}_{3}, 36 \%\right)$.

Tetramethylethanediylbis(3-methylcyclopentadienyl)vanadium dichloride (3b). The same procedure and the same molar ratios used to synthesize $3 a$ were used to give $76 \%\left(\mathrm{CH}_{3}\right)_{4} \mathrm{C}_{2}\left(3-\left(\mathrm{CH}_{3}\right)\right.$ $\left.\mathrm{C}_{5} \mathrm{H}_{3}\right)_{2} \mathrm{VCl}_{2}$ (3b) starting from $\mathrm{V}(\mathrm{acac})_{3}$. IR spectrum (Nujol, $\left.\mathrm{KBr}, \mathrm{cm}^{-1}\right): 3117(\mathrm{w}), 3081(\mathrm{w}), 1502$ (w), $1455(\mathrm{~s}), 1367(\mathrm{~s}), 1261$ (w), $1092(\mathrm{~m}), 1073(\mathrm{~m}), 1060(\mathrm{~m}), 1029(\mathrm{~m}), 865(\mathrm{~m}), 841(\mathrm{w})$, $824(\mathrm{w}), 801(\mathrm{~m})$. For $\mathrm{C}_{18} \mathrm{H}_{24} \mathrm{Cl}_{2} \mathrm{~V}(362.2)$ calculated: $59.69 \% \mathrm{C}, 6.68 \% \mathrm{H}$; found: $58.89 \% \mathrm{C}, 6.72 \% \mathrm{H}$. Mass spectrum (El, $\left.70 \mathrm{eV}, 170{ }^{\circ} \mathrm{C}\right): \mathrm{m} / z .361\left(\mathrm{M}^{+}, 20 \%\right), 326\left(\mathrm{M}^{+}-\mathrm{Cl}, 39 \%\right), 288\left(\mathrm{M}^{+}-2 \mathrm{HCl}-\mathrm{H}\right.$, $27 \%), 205\left(\mathrm{M}^{+}-\mathrm{C}_{9} \mathrm{H}_{13}, 100 \%\right), 170\left(\mathrm{M}^{+}-\mathrm{C}_{4} \mathrm{H}_{13}-\mathrm{Cl}, 45 \%\right)$.

Tetramethylethanediylbis(3-t-butylcyclopentadienyl)vanadium dichloride (3c). $0.54 \mathrm{~g}$ (1.55 mmol) of $\mathrm{V}(\mathrm{acac})_{3}$ were reacted with $1.55 \mathrm{mmol}$ of the dimagnesium salt $1 \mathrm{c}$ in $150 \mathrm{ml}$ of THF. After stirring for $16 \mathrm{~h}$, the solvent was removed in vacuo. The remaining solid was stirred in $5 \mathrm{ml}$ of methylene chloride and then $100 \mathrm{ml}$ of pentane were added. The mixture was filtered and the filtrate freed from solvent. The solid residue was taken up in THF and $1.6 \mathrm{mmol} \mathrm{AgCl}$ added. After stirring for $12 \mathrm{~h}$, the suspension was filtered and solvent removed from the filtrate. The residue was extracted with hexane in a Soxhlet apparatus. The extract was cooled to $-80^{\circ} \mathrm{C}$ and the yellow-green solid isolated by filtration to give $74 \%\left(\mathrm{CH}_{3}\right)_{4} \mathrm{C}_{2}\left(3-\left(\left(\mathrm{CH}_{3}\right)_{3} \mathrm{C}\right)-\mathrm{C}_{5} \mathrm{H}_{3}\right)_{2} \mathrm{VCl}_{2}$ (3c). IR spectrum (Nujol, $\left.\mathrm{KBr}, \mathrm{cm}^{-1}\right)$ : $3135(\mathrm{~m}), 3117(\mathrm{~m}), 1497(\mathrm{~s}), 1399(\mathrm{w}), 1382(\mathrm{~m}), 1375(\mathrm{~m}), 1365(\mathrm{~s}), 1358(\mathrm{~m}), 1242(\mathrm{~m}), 1169(\mathrm{w})$, $1076(\mathrm{~m}), 877(\mathrm{~m}), 824(\mathrm{~m})$. For $\mathrm{C}_{24} \mathrm{H}_{36} \mathrm{Cl}_{2} \mathrm{~V}(446.4)$ calculated: $64.58 \% \mathrm{C}, 8.13 \% \mathrm{H}$; found: $64.1 \% \mathrm{C}$, 8. $08 \%$ H. Mass spectrum (El, $\left.70 \mathrm{eV}, 2000^{\circ} \mathrm{C}\right)$ : $\mathrm{m} / 2.445\left(\mathrm{M}^{+}, 27 \%\right), 410\left(\mathrm{M}^{+}-\mathrm{Cl}, 100 \%\right), 373\left(\mathrm{M}^{+}-2 \mathrm{HCl}\right.$, $1 \%), 233\left(\mathrm{M}^{+}-\mathrm{Cl}-\mathrm{C}_{12} \mathrm{H}_{1 \%}, 76 \%\right)$.

Tetramethylethanediylbis(3-t-butylcyclopentudienyl)vanadiumbis(t-butylisenitrile) chloride $\left(4 \mathrm{c}^{+} \mathrm{Cl}^{-}\right)$. To a solution of $1 \mathrm{mmol}$ of the vanadium(III) starting material in $50 \mathrm{ml}$ of THF, $1 \mathrm{mmol}$ of ligand salt 1c in $50 \mathrm{ml}$ THF was added dropwise. After stirring for $6 \mathrm{~h}$ at the temperature given in Table I, the reaction mixture was stirred at room temperature for another $10 \mathrm{~h}$. The solvent was removed in vacuo, the residue stirred in $5 \mathrm{ml}$ of methylene chloride; then $100 \mathrm{ml}$ of pentane were added. The suspension was filtered and the solution reduced to a small volume. Addition of $(0.23 \mathrm{ml}(2 \mathrm{mmol})$ of $t$-butylisonitrile resulted in a slow color change from blue to brown. After $16 \mathrm{~h}$, the solvent was removed in vacuo and the remaining solid examined by 'H NMR spectroscopy. Purification of the brown solid wats achieved by recrystallization from $\mathrm{CH}_{2} \mathrm{Cl}_{2}$-ether (yields and diastereoisomer ratios, see Table I). IR spectrum (Nujol, $\left.\mathrm{KBr}, \mathrm{cm}^{-1}\right): \mathrm{v}(\mathrm{CN}): 2$ 125, 2 112, 2 102; rac-4a+ $\mathrm{Cl}^{-}$: ${ }^{1} \mathrm{H}$ NMR spectrum $\left(\mathrm{CDCl}_{3}, 250 \mathrm{MHz}\right): \delta\left(0.99 \mathrm{~s}, 6 \mathrm{H}\left(\mathrm{CH}_{3}\right.\right.$-bridge, $\mathrm{Me}$ next to $\left.\mathrm{C}(2)\right) ; 1.05 \mathrm{~s}, 6 \mathrm{H}\left(\mathrm{CH}_{3}\right.$-bridge, Me next to $\mathrm{C}(5)) ; 1.23 \mathrm{~s}, 18 \mathrm{H}\left(\left(\mathrm{CH}_{3}\right)_{3} \mathrm{C}-\mathrm{cp}\right) ; 1.43 \mathrm{~s}, 18 \mathrm{H}\left(\left(\mathrm{CH}_{3}\right)_{3} \mathrm{C}-\mathrm{NC}\right) ; 4.68 \mathrm{~m}, 2 \mathrm{H}\left(\beta-(4)-\mathrm{C}_{5} \mathrm{H}_{3}\right)$; $4.90) \mathrm{m}, 2 \mathrm{H}\left(\alpha-(2)-\mathrm{C}_{5} \mathrm{H}_{3}\right) ; 4.95 \mathrm{~m}, 2 \mathrm{H}\left(\alpha-(5)-\mathrm{C}_{5} \mathrm{H}_{3}\right)$. ' $\mathrm{H}$ NMR spectrum $\left(\left(\mathrm{CD}_{3}\right)_{2} \mathrm{CO}, 250 \mathrm{MHz}\right): \delta$ $1.07 \mathrm{~s}, 6 \mathrm{H}\left(\mathrm{CH}_{3}\right.$-bridge, Me next to $\left.\mathrm{C}(2)\right) ; 1.15 \mathrm{~s}, 6 \mathrm{H}\left(\mathrm{CH}_{3}\right.$-bridge, Me next to $\left.\mathrm{C}(5)\right) ; 1.34 \mathrm{~s}, 18 \mathrm{H}$ $\left(\left(\mathrm{CH}_{3}\right)_{3} \mathrm{C}-\mathrm{cp}\right) ; 1.54 \mathrm{~s}, 18 \mathrm{H}\left(\left(\mathrm{CH}_{3}\right)_{3} \mathrm{C}-\mathrm{NC}\right) ; 5.04 \mathrm{~m}, 2 \mathrm{H}\left(\beta-(4)-\mathrm{C}_{5} \mathrm{H}_{3}\right) ; 5.22 \mathrm{~m}, 2 \mathrm{H}\left(\alpha-(2)-\mathrm{C}_{5} \mathrm{H}_{3}\right) ;$ $5.33 \mathrm{~m}, 2 \mathrm{H}\left(\alpha_{2}-(5)-\mathrm{C}_{5} \mathrm{H}_{3}\right) \cdot{ }^{1.3} \mathrm{C}$ NMR spectrum $\left(63 \mathrm{MHz}, \mathrm{CDCl}_{3}\right): \delta 25.37\left(\mathrm{C}_{2}\left(\mathrm{CH}_{3}\right)_{2}\right.$-bridge. Me next

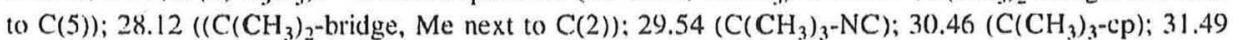

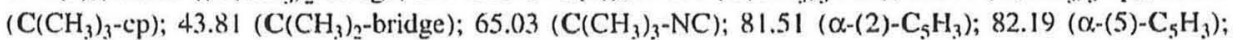
$95.85\left(\beta-(4)-\mathrm{C}_{5} \mathrm{H}_{3}\right): 128.96\left(\beta-(3)-\mathrm{C}_{5} \mathrm{H}_{3}\right): 133.44$ (bridgehead-(1)- $\left.\mathrm{C}_{5} \mathrm{H}_{3}\right)$. meso- $4 \mathrm{c}^{+} \mathrm{Cl}^{-}:{ }^{1} \mathrm{H}$ NMR $\left(\left(\mathrm{CD}_{3}\right)_{2} \mathrm{CO}, 250 \mathrm{MHz}\right): \delta 1.06,1.292 \mathrm{~s}, 12 \mathrm{H}\left(\mathrm{CH}_{3}\right.$-bridge $) ; 1.25 \mathrm{~s}, 18 \mathrm{H}\left(\left(\mathrm{CH}_{3}\right)_{3} \mathrm{C}\right.$-cp $) ; 1.59,1.56$ $2 \mathrm{~s}, 18 \mathrm{H}\left(\left(\mathrm{CH}_{3}\right)_{3} \mathrm{C}-\mathrm{NC}\right) ; 4.86,5.26,5.67 \mathrm{~m}, 6 \mathrm{H}\left(\mathrm{C}_{5} \mathrm{H}_{3}\right)$. 
TABLE IV

\begin{tabular}{|c|c|c|c|c|}
\hline Parameter & $2 a$ & $4 a^{+} \mathrm{Cl}^{-}$ & $\mathrm{Sa}^{*} \mathrm{BPh}_{4} \overline{4}$ & $\mathrm{Sc}^{+} \mathrm{BPh}_{4}$ \\
\hline Formula & $\mathrm{C}_{16} \mathrm{H}_{20} \mathrm{VCl}$ & $\mathrm{C}_{26} \mathrm{H}_{38} \mathrm{~N}_{2} \mathrm{VCl}$ & $\mathrm{C}_{45} \mathrm{H}_{47} \mathrm{BO}_{2} \mathrm{~V}$ & $\mathrm{C}_{53} \mathrm{H}_{63} \mathrm{BO}_{2} \mathrm{~V}$ \\
\hline Molecular weight & 298.73 & 464.99 & 681.62 & 793.8 \\
\hline Color, habit & blue needles & red cuboid & green needles & green needle \\
\hline Crystal size & $0.2 \times 0.2 \times 0.4$ & $0.3 \times 0.2 \times 0.2$ & $0.2 \times 0.2 \times 0.4$ & $0.3 \times 0.3 \times 0.3$ \\
\hline Space group ${ }^{a}$ & $P 2_{1} / n$ & $P 2_{1} 2_{1} 2_{1}$ & $P 2_{1} / c$ & $P 2_{1} / n$ \\
\hline$a, \AA$ & $7.574(2)$ & $12.012(6)$ & $9.669(3)$ & $13.061(5)$ \\
\hline$b, \AA$ & $18.691(4)$ & $12.238(6)$ & $18.088(8)$ & $22.119(5)$ \\
\hline$c . \AA$ & $9.933(2)$ & $17.589(8)$ & $20.981(5)$ & $15.602(6)$ \\
\hline$\beta .{ }^{\circ} \quad 0$ & $95.33(2)$ & & $93.27(2)$ & $92.70(3)$ \\
\hline Volume, $\AA^{3}$ & $1400(5)$ & $2586(2)$ & $3636(2)$ & $4502(3)$ \\
\hline$D_{\mathrm{c}}, \mathrm{g} \mathrm{cm}^{-3}$ & 1.417 & 1.194 & 1.236 & 1.171 \\
\hline Absorption coefficient $(\mu), \mathrm{cm}^{-1}$ & 0.858 & 0.489 & 0.296 & 0.249 \\
\hline Temperature, $\mathrm{K}$ & 235 & 238 & 235 & 245 \\
\hline Weighting scheme & $\sigma^{2}(F)+0.0004 F^{2}$ & $\sigma^{2}(F)+0.0002 F^{2}$ & $\sigma^{2}(F)+0.0003 F^{2}$ & $\sigma^{2}(F)+0.0004 F^{2}$ \\
\hline $2 \theta$ range, $^{\circ}$ & 3.0 to 50.0 & 4.0 to 40.0 & 4.0 to 45.0 & 4.0 to 50.0 \\
\hline Scan speed, ${ }^{\circ} \min ^{-1}$ & 1.50 to 14.65 & 1.50 to 14.65 & 1.50 to 14.65 & 1.5 to 14.65 \\
\hline Scan range, ${ }^{\circ}$ & 0.85 & 0.80 & 0.70 & 0.60 \\
\hline Reflection collected & 1721 & 1430 & 5335 & 8564 \\
\hline Independent reflections & 1648 & 1413 & 4796 & 7950 \\
\hline Observed reflections $(F>4 \sigma(F)$ ) & 1362 & 922 & 2909 & 4309 \\
\hline Solution (SHELXTL PLUS) & direct methods & Patterson & Patterson & direct method \\
\hline Number of parameters refined & 153 & 271 & 442 & 514 \\
\hline$R_{F} \% \%$ & 3.12 & 5.92 & 5.33 & 5.39 \\
\hline$w_{F}{ }^{d}, \%$ & 3.88 & 5.03 & 4.97 & 5.48 \\
\hline \multirow{2}{*}{$\begin{array}{l}\text { Goodness-of-fit } \\
\text { Residual density, } 10^{-6} \mathrm{e} \mathrm{pm}^{-3}\end{array}$} & 1.35 & 1.39 & 1.43 & 1.27 \\
\hline & 0.32 & 0.41 & 0.25 & 0.32 \\
\hline
\end{tabular}

Conditions: Syntex/Siemens-P3 four-circle diffractometer, MoK $\alpha$ radiation, $71.073 \mathrm{pm}$, graphite monochromator.

${ }^{a}$ Monoclinic, $Z=4 ;{ }^{b}$ Wyckoff scan: ${ }^{c} R_{F}=\sum \| F_{\mathrm{o}}|-| F_{\mathrm{c}}|| / \Sigma\left|F_{\mathrm{c}} \delta\right|:{ }^{d}{ }_{w} R_{F}=\left|\Sigma w\left(\left|F_{\mathrm{o}}\right|-\left|F_{\mathrm{c}}\right|\right)^{2} / \Sigma F_{\mathrm{o}}{ }^{2}\right|^{1 / 2}$. 
Tetramethylethanediylbis(3-t-Intylcyclopentadienyl)vanadium-rac-1,1'-bi-2-naphtholate (jac-6c). To a toluene solution containing $0.41 \mathrm{~g}(0.92 \mathrm{mmol})$ of the dichloride $3 \mathrm{c}$ (both diastereoisomers) and $0.26 \mathrm{~g}(0.92 \mathrm{mmol})$ rac-1,1'-bi-2-naphthol $0.25 \mathrm{ml}(1.8 \mathrm{mmol})$ triethylamine was added. In the course of $2 \mathrm{~h}$ the solution turned deep red. After stirring overnight, insoluble triethylammonium hydrochloride was removed by filtration. The filtrate was concentrated in vacue and chromatographed over a column of silanized silica gel with pentane as eluent. Evaporation of the deep red fraction and drying the solid residue in vacuo yielded $0.42 \mathrm{~g}$ of the racemate of $\left(\mathrm{CH}_{3}\right)_{4} \mathrm{C}_{2}\left(3-\left(\left(\mathrm{CH}_{3}\right)_{3} \mathrm{C}\right)\right.$ $\left.\mathrm{C}_{5} \mathrm{H}_{3}\right)_{2} \mathrm{VC}_{20} \mathrm{H}_{12} \mathrm{O}_{2}$ (rac-6c, 69\% yield). IR spectrum (Nujol, $\mathrm{KBr}, \mathrm{cm}^{-1}$ ): $1588(\mathrm{~m}), 1499(\mathrm{~m}), 1419(\mathrm{~m})$, $1382(\mathrm{~m}), 1365(\mathrm{~s}), 1280(\mathrm{~m}), 1246(\mathrm{~s}), 1232(\mathrm{~m}), 744(\mathrm{~m})$. For $\mathrm{C}_{44} \mathrm{H}_{48} \mathrm{O}_{2} \mathrm{~V}(660.0)$ calculated: $80.08 \% \mathrm{C}, 7.33 \% \mathrm{H}$; found: $79.43 \% \mathrm{C}, 7.52 \% \mathrm{H}$. Mass spectrum (El, $\left.70 \mathrm{eV}, 175{ }^{\circ} \mathrm{C}\right): \mathrm{m} / \mathrm{z} 659\left(\mathrm{M}^{+}\right.$. $4 \%), 497\left(\mathrm{M}^{+}-\mathrm{C}_{12} \mathrm{H}_{18}, 2 \%\right), 324\left(\mathrm{M}^{+}-\mathrm{C}_{20} \mathrm{H}_{12} \mathrm{O} 2 \mathrm{~V}, 42 \%\right), 284\left(\mathrm{M}^{+}-\mathrm{C}_{24} \mathrm{H}_{36} \mathrm{~V}, 100 \%\right)$.

Tetramethylethanedivlbis(3-t-buttylcyclopentadienyl)vanadium- $R-1, I^{\prime}-b i-2$-naphtholate $(R-6 \mathrm{c})$. A procedure analogous to that described above for rac-6c, but conducted with one half equivalent of $R-(+)$ 1,1'-bi-2-naphthol, gave one enantiomer of $6 \mathrm{c}$. with $[\alpha]_{\mathrm{D}}=2224^{\circ}(d=1,13.1 \mathrm{mg} 6 \mathrm{c}$ in $1.5 \mathrm{~m}]$ $\mathrm{CHCl}_{3}$ ).

Tetramethylethanedivlbis(3-t-butylcyclopentadienyl)acetylacetonato vanadium hexaftuorophosphate $\left(5 \mathrm{c}^{+} \mathrm{PF}_{6}{ }^{-}\right)$. A reaction mixture containing the binaphtholate $6 \mathrm{c}$ and unreacted dichloride $3 \mathrm{c}$ was freed from triethylammonium hydrochloride by filtration, evaporated to dryness and then stirred with $20 \mathrm{ml}$ water and $1 \mathrm{ml}$ acetylacetone for one hour. After collecting the insoluble binaphtholate $6 \mathrm{c}$ by filtration, addition of $0.3 \mathrm{~g}(1.6 \mathrm{mmol})$ of $\mathrm{KPF}_{6}$ to the green aqueous filtrate gave a precipitate of $0.23 \mathrm{~g}$ of $5 \mathrm{c}^{+} \mathrm{PF}_{6}\left(40 \%\right.$ theoretical yield, based on dichloride $3 \mathrm{c}$ ). IR spectrum (Nujol, $\left.\mathrm{KBr}, \mathrm{cm}^{-1}\right): 1581$ (s), $1519(\mathrm{~s}), 1498(\mathrm{~m}), 1403(\mathrm{~m}), 1279(\mathrm{~m}), 1261(\mathrm{~m}), 1021(\mathrm{~m}), 878(\mathrm{~m}), 836(\mathrm{~s}), 771(\mathrm{~m})$. For $\mathrm{C}_{29} \mathrm{H}_{43} \mathrm{~F}_{6} \mathrm{O}_{2} \mathrm{PV}(619.6)$ calculated: $56.22 \% \mathrm{C}, 7.0 \% \mathrm{H}$; found: $56.63 \% \mathrm{C}, 7.1 \% \mathrm{H}$.

\section{Crystal Structure Determinations}

Crystals of complex 2a were obtained from ether-hexane solutions at $0{ }^{\circ} \mathrm{C}$, crystals of $4 \mathrm{a}^{+} \mathrm{Cl}^{-}$, $5 \mathrm{a}^{+} \mathrm{B}\left(\mathrm{C}_{6} \mathrm{H}_{5}\right)_{4}$ and $5 \mathrm{c}^{+} \mathrm{B}\left(\mathrm{C}_{6} \mathrm{H}_{5}\right)_{4}^{-}$were obtained by slow crystallization from $\mathrm{CH}_{2} \mathrm{Cl}_{2}$-ether solutions. Space groups, unit cell dimensions and diffraction intensities were determined on a Syntex/SiemensP3 four-circle diffractometer. Table IV summarizes the experimental data for the crystallographic structure determination. Additional data can be obtained from Fachinformationszentrum Karlsruhe, 76344 Eggenstein-Leopoldshafen 2, upon quotation of deposit number CSD-59372, the authors and the journal reference for this article.

We thank Dr A. Geyer and S. Popp for help with two-dimensional NMR measurements and cyclovoltammetric measurements, respectively, and Dr M. Huttenloch for helpfil discussions. Financial support of this work by Volkswagen Foundation and BMBF is gratefully acknowledged.

\section{REFERENCES}

1. Schaper F., Rentzsch M., Prosenc M.-H., Rief U., Schmidt K., Brintzinger H. H.: J. Organomet. Chem., in press.

2. Gyepes R., Hiller J., Thewalt U., Polášek M., Šindelár̆ P., Mach K.: J. Organomet. Chem. 516 , 177 (1996); Varga V., Hiller J., Polášek M., Thewalt U., Mach K.: J. Organomet. Chem. 515, 57 (1996); Varga V., Petrusová L., Čejka J., Hanuš V., Mach K.: J. Organomet. Chem. 509, 235 (1996).

3. Dorer B., Diebold J., Weyand O., Brintzinger H. H.: J. Organomet. Chem. 427, 245 (1992).

Collect. Czech. Chem. Commun. (Vol. 62) (1997) 
4. Pasquali M., Marchetti F., Floriani C.: Inorg. Chem. 18, 2401 (1979)

5. Nieman J., Scholtens H., Teuben J. H.: J. Organomet. Chem. 186, C12 (1980).

6. Morán M.: Transition Met. Chem. 6, 42 (1981); Calderazzo F., Fachinetti G., Floriani C.: J. Am. Chem. Soc. 96, 3695 (1974).

7. Doyle G., Tobias R. S.: Inorg. Chem. 7, 2479 (1968).

8. Thewalt U., Honold B.: J. Organomet. Chem. 348, 291 (1988).

9. Erickson M., Fronczek F., Mc Laughlin M. L.: J. Organomet. Chem. 415, 75 (1991).

10. Fieselmann B. F., Stucky G. D.: J. Organomet. Chem. 137, 43 (1977).

11. Burger P., Diebold J., Gutmann S., Hund H.-U., Brintzinger H. H.: Organometallics 11,1319 (1992).

12. Hambley T. W., Hawkins C. J., Kabanos T. A.: Inorg. Chem. 26, 3740 (1987).

13. Manzer L.: Inorg. Chem. I7, 1552 (1978).

14. Seidel W., Kreisel F.: Z. Anorg. Allg. Chem. 577, 229 (1989).

15. Schwemlein H., Brintzinger H. H.: J. Organomet. Chem. 254, 69 (1983).

16. Gutmann S., Burger P., Hund H.-U., Hofmann J., Brintzinger H. H.: J. Organomet. Chem. 369, 343 (1989).

17. Gutmann S., Burger P., Prosenc M. H., Brintzinger H. H.: J. Organomet. Chem. 397, 21 (1990). 